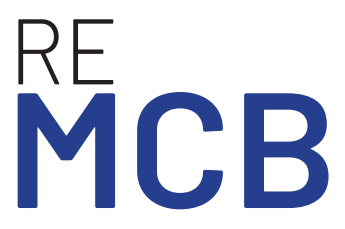

Revista Ecuatoriana de Medicina y Ciencias Biológicas Volumen 42. No. 2, Nov 2021

\section{Pseudolycopodiella iuliformis (Lycopodiaceae, Lycopodielloideae) in Ecuador and Peru; a disjunct species between the Guyana Shield and the Cordillera del Cóndor}

\section{Pseudolycopodiella iuliformis (Lycopodiaceae, Lycopodielloideae) en Ecuador y Perú; una especie disyunta entre el Escudo Guyanés y la Cordillera del Cóndor}

Nicolás Zapata1', Álvaro J. Pérez ${ }^{1 *}$, Kevin Burgess², Edison Rea 2,1, David A. Neill ${ }^{3}$, Daniela Cevallos ${ }^{4}$, Claes Persson 5 , Benjamin Øllgaard ${ }^{6}$
'Herbario QCA, Escuela de Ciencias Biológicas, Pontificia Universidad Católica de Ecuador, Av. 12 de octubre 1076 y Roca, Apartado 1701-2184, Quito, Ecuador.

2Department of Biology, College of Letters \& Sciences, Columbus State University, University System

of Georgia, 4225 University Ave,

Columbus, GA 31907, USA.

3Universidad Estatal Amazónica,

Paso lateral, Puyo, Pastaza, Ecuador.

${ }^{4}$ Grupo de Investigación en

Biodiversidad, Medio Ambiente y

Salud (BIOMAS), Universidad de las Américas (UDLA), Vía Nayón s/n,

Quito, Ecuador.

${ }^{5}$ Department of Biological and Environmental Sciences, University of Gothenburg, P.O. Box 461, 40530 Göteborg, Sweden.

${ }^{6}$ Herbarium AAU, Science Museums, and Section for Ecoinformatics and Biodiversity, Department of Biology, Building 1137, University of Aarhus, DK-8000 Aarhus, Denmark.

*Corresponding author: ajperezc@ puce.edu.ec

Recibido 31-07-2021

Aceptado 21-11-2021

DOI: 10.26807/remcb.v42i2.903

e-ISSN 2477-9148

(c) 2021. This paper is published under a CC BY-NC 4.0 license.

\section{Citation:}

Zapata N, Pérez AJ, Burgess K, Rea

E, Neill DA, Cevallos D, Persson C

Øllgaard B. 2021. Pseudolycopodiella iuliformis (Lycopodiaceae,

Lycopodielloideae) in Ecuador and Peru; a disjunct species

between the Guyana Shield and

the Cordillera del Cóndor. Revista

Ecuatoriana de Medicina y Ciencias

Biológicas 42(2): 133-139 doi:

10.26807/remcb.v42i2.903
Abstract.- Recent floristic surveys in Ecuador and Peru have found many disjunct species between the Guyana Shield and the Cordillera del Cóndor. Here, we report the occurrence of another disjunct species between these two ranges, Pseudolycopodiella iuliformis (Underw. \& F.E. Lloyd) Holub, recently discovered in the Cordillera del Cóndor range. We present a morphological description, photographic documentation, and an updated distribution map. In addition, we highlight the morphological differences between P. iuliformis and its congeners historically recorded for Ecuador and Peru. This research highlights an urgent need for further exploration of the Cordillera del Cóndor range, as it seems likely, based on our findings and those of previous floristic surveys, that additional disjunct species are likely to be found in the area.

Keywords: Andean tepui, Conservation, Distribution range, Disjunct species, Lycophytes, Phytogeography, Taxonomy

Resumen.- Recientes estudios florísticos en Ecuador y Perú han registrado varias especies disyuntas entre el Escudo Guyanés y la Cordillera del Cóndor. Aquí, reportamos la ocurrencia de otra especie disyunta entre estas dos cordilleras, Pseudolycopodiella iuliformis (Underw. \& F.E. Lloyd) Holub, recientemente registrada en la Cordillera del Cóndor. Presentamos una descripción morfológica, fotografías, y un mapa de distribución actualizado. Adicionalmente, resaltamos las diferencias morfológicas entre $P$. iuliformis y sus congéneres históricamente registrados en Ecuador y Perú. Esta investigación enfatiza la necesidad urgente de una mayor exploración de la Cordillera del Cóndor, ya que parece probable, con base a nuestros hallazgos y los de estudios florísticos previos, que se encontrarán más especies disyuntas en esta área.

Palabras clave: Conservación, Especies disyunta, Fitogeografía, Licofitos, Rango de distribución, Taxonomía, Tepuy Andino.

\section{Introduction}

Pseudolycopodiella Holub consists of $\sim 15$ poorly understood species distributed in tropical and temperate regions of western Asia, Australia, and western North and South America (Holub 1983, Øllgaard and Windisch 2016). In the Neotropics, Brazil has the highest diversity of species (seven), followed by Venezuela, with four species. For western South America in particular, only Pseudolycopodiella meridionalis (Underw. \& F.E. Lloyd) Holub is recorded in Ecuador (Øllgaard 2016), whereas Pseudolycopodiella contexta (Mart.) Holub and Pseudolycopodiella caroliniana (L.) Holub var. mesetarum (B.Øllg.) B.Øllg are recorded in Peru (Ulloa Ulloa et al. 2017).

Pseudolycopodiella can be distinguished from other South American members of the subfamily Lycopodielloideae (i.e., Lycopodiella Holub, Palhinhaea Vascon. \& Franco) by the following character states: 1) sporophytes with prostrate, rooting, indeterminate, isophyllous to strongly anisophyllous, horizontally branching shoots and dorsally arising, erect, simple strobiliferous branches with leaves that conform with those of the prostrate shoots or leaves that are strongly reduced and distant; 2) sporophylls arranged in alternating whorls of 3-5, rarely decussate, forming 4-10 (-12) longitudinal ranks, free, not enclosing the sporangia at maturity, without 
veinal mucilage canals; and 3) sporangia isovalvate, reniform, widely attached to the sporophyll stalk: sporangium epidermis cells with incompletely lignified or with incomplete semiannular thickenings (Øllgaard 2014, Øllgaard and Windisch 2016).

Explorations in the Ecuadorian and Peruvian Cordillera del Cóndor range have revealed several disjunct plant genera/species with the Guyana Shield, i.e., Stenopadus (Asteraceae), Digomphia densicoma (Mart. ex DC.) Pilg. (Bignoniaceae), Everardia montana Ridl. (Cyperaceae), Dendrothrix (Euphorbiaceae), Euceraea (Salicaceae), Phainantha (Melastomataceae), Podocarpus tepuiensis J. Buchholz \& N.E. Gray (Podocarpaceae), Pterozonium (Pteridaceae), Perissocarpa (Ochnaceae), Retiniphyllum (Rubiaceae), Bonnetia (Bonnetiaceae), and Aratitiyopea (Xyridaceae) (Berry et al. 1995, Neill 2005, 2007, Wurdack 2017); several new taxa have also been discovered (Gradstein et al. 2019, Mashburn et al. 2020, Pérez et al. 2020, 2021). The disjunct distribution of plant species between the Cordillera del Cóndor and the Guyana Shield may be explained by the two regions having a similar substrate (i.e., sandstone rock), though the age of their formation differs (Gregory-Wodzicki 2000). Recent studies suggest that plant species have migrated to the Cordillera del Cóndor region via occasional, long-distance dispersion events in relatively recent times, following its diversification over a more extended period in the Guiana Shield region (Neill 2007).

For this study, we identify specimens collected from the Cordillera del Cóndor that are deposited at the Herbarium QCA; one of these specimens is Pseudolycopodiella iuliformis (Underw. \& F.E. Lloyd) Holub (Figure 1), which is the first recording of this species as a disjunct between the Cordillera del Cóndor range (Southern Ecuador - Northern Peru) and the tepuis of the Guyana Shield in southern Venezuela and northern Brazil. Based on this finding and those of previous plant collecting expeditions to the region, we emphasize the importance of conducting additional floristic explorations to contribute to our understanding of the diversity, endemism, and phytogeography of the Cordillera del Cóndor range. This area is also severely threatened due to deforestation and mining activities.

Here, we present a morphological description, photographic documentation, and an updated distribution map for P. iuliformis, and highlight the morphological differences between P. iuliformis and its congeners in Ecuador and Peru. Currently, two species of Pseudolycopodiella are recorded for Ecuador, and three species for Peru.

\section{Materials and methods}

Psedolycopodiella specimens collected from the Cerro Plateado Biological Reserve and the Machinaza region in the Zamora-Chinchipe Province, southern Ecuador, formed the basis of this study. Additionally, we revised material from QCA and QCNE herbaria. We based identification on the pertinent literature, high-resolution images for the type of material of Neotropical taxa (Tropicos database, https://www.tropicos.org/ and the JSTOR Global Plants website http: // plants.jstor.org) and the Pteridoportal website (www.Pteridoportal.org).

Dry material and pictures of our specimens formed the basis for updating the morphological description of P. iuliformis (Øllgaard and Windisch 2016). All measurements were performed on dry material, and fine-scale observations and measurements of reproductive structures were made with a dissecting microscope.

\section{Taxonomy}

Pseudolycopodiella iuliformis (Underw. \& F. E. Lloyd) Holub, Folia Geobot. Phytotax. 18: 442. 1983. Lycopodium iuliforme Underw. \& F. E. Lloyd, Bull. Torrey Bot. Club 33: 120. 1906. - Lycopodiella iuliformis (Underw. \& F. E. Lloyd) B. Øllg., Opera Bot. 92: 176. 1987.

Type: Venezuela: Summit of Roraima, 8600 ft, McConnell \& Quelch 572 (Holotype NY! 143999).

Figure 1, 2

Horizontal shoots closely appressed to the ground, 5-20 cm long, rooted with short intervals, sparsely to densely branching in the horizontal plane, usually forming small mats, bearing stiffly erect, dorsally arising, simple, 6-30 cm tall strobiliferous branches. Horizontal shoots densely 

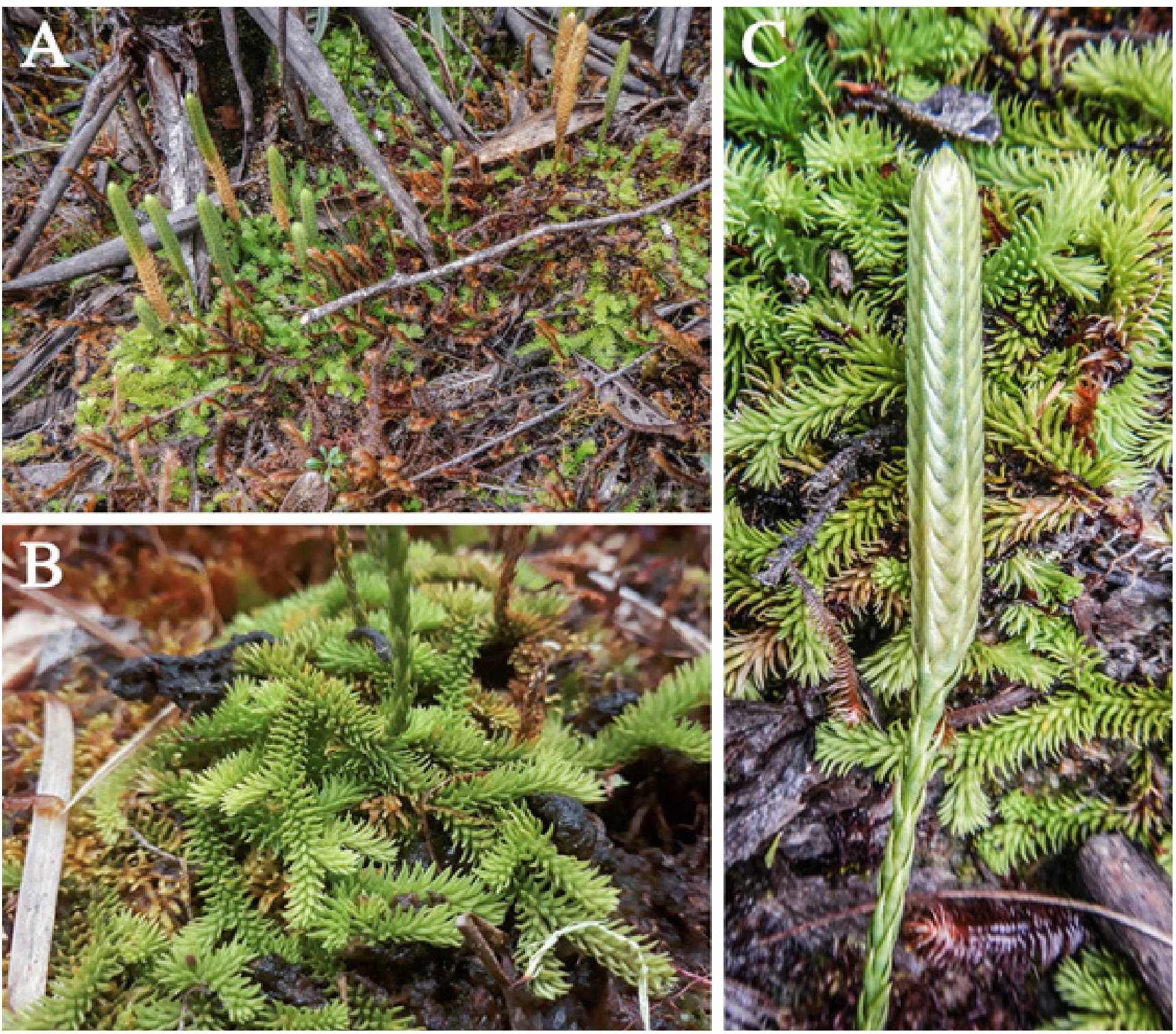

Figura 1. Pseudolycopodiella iuliformis. A. Habitat in Cerro Plateado Reserve; mat growing under thick organic matter surrounded by bryophytes. B. Creeping shoots entirely isophyllous. C. Detail of young strobilus. Photographs: A, B by Álvaro J. Pérez, C by Nicolás Zapata.

covered on all sides by leaves, 4-10 mm diam. incl. leaves. Stems excl. leaves 1-3 mm thick. Leaves of horizontal shoots uniform, usually upward secund and curved, acicular, flattened with a subterete to compressed leaf base (angular when dried), or sometimes terete or angular throughout, 3-6 $\times$ 0.4-0.8 (-1) mm, with smooth margins. Leaf bases not, or only slightly acroscopically adnate, short to long decurrent. Erect strobiliferous shoots $3-4 \mathrm{~mm}$ diam. incl leaves, $1.5-2 \mathrm{~mm}$ excl. leaves, with uniform, radially arranged leaves. Vegetative leaves of erect shoots borne in alternating, irregular whorls of 3-6, 2-4 mm apart, forming 8-12 obscure longitudinal ranks, appressed throughout, flattened, subulate, ca. $5 \times$ ca. $0.8 \mathrm{~mm}$, evenly tapering. Strobili 2.5-11 cm long, 3-5 mm diam. with appressed sporophylls, to $14 \mathrm{~mm}$ in diam. with distended sporophylls. Sporophylls borne in alternating whorls of 5-6, forming 10-12 longitudinal ranks, subpeltate, with a basiscopic, compressed membranaceous wing on the stalk, the exterior face with a widely ovate to rhombic basal part and an abruptly to evenly tapering, long apex, 4-8 $\times$ 1.5-2 mm, with finely erose-dentate margins. Sporangia borne on the sporophyll base, reniform, isovalvate, $1.5-2 \mathrm{~mm}$ wide. 


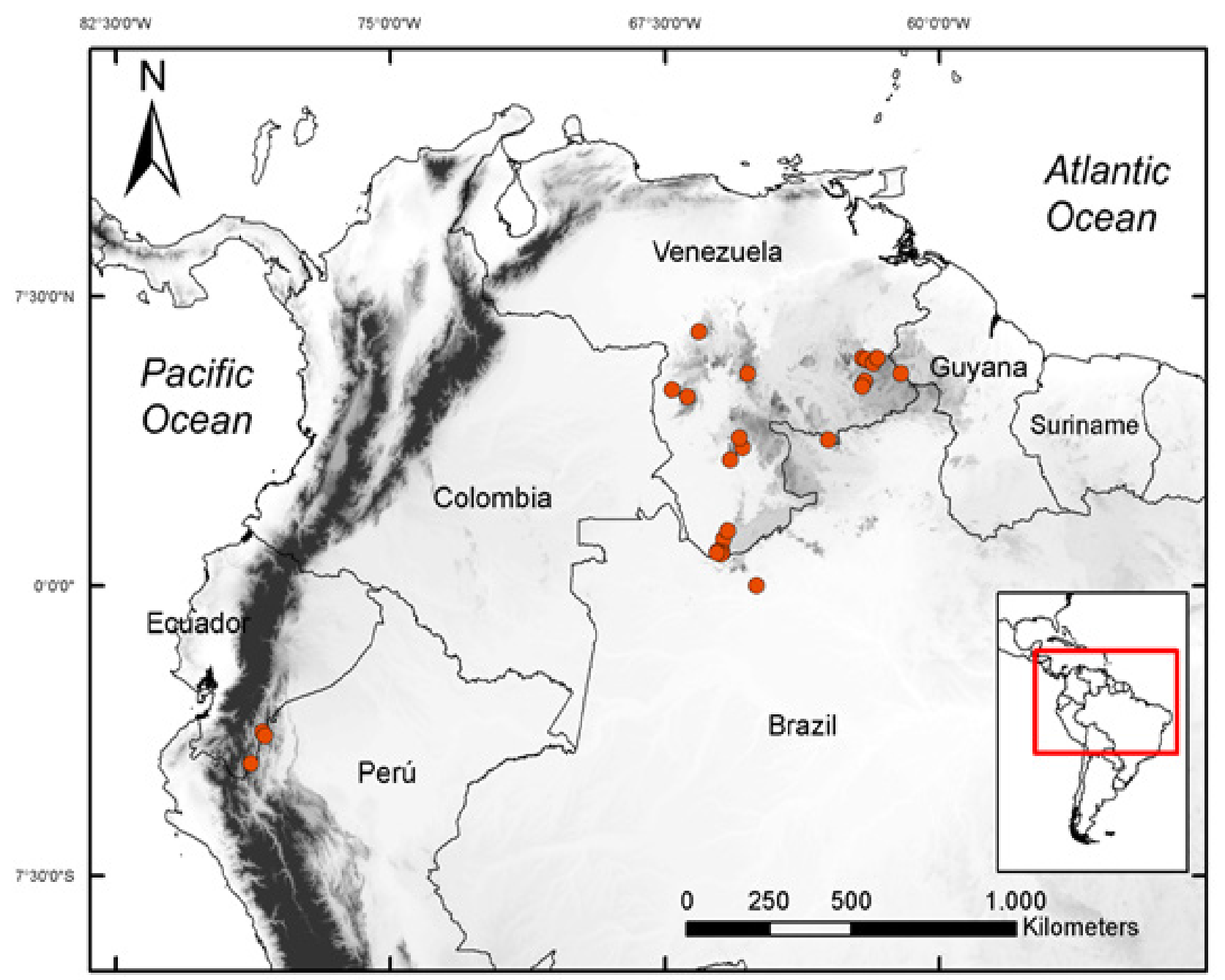

Figure 2. Distribution map of Pseudolycopodiella iuliformis

Distribution and habitat

Pseudolycopodiella iuliformis is a highly variable species previously considered endemic to the Guyana Highlands in Venezuela and Brazil, which grows in sandy, nutrient-poor, acidic soils (Øllgaard and Windisch 2016). The focal populations of P. iuliformis recorded in the Cordillera del Cóndor range of Ecuador and Peru grow in similar abiotic conditions, supporting a disjunct distribution between two similar geological formations, but separated by more than 1500 km (Figure 2). The Guyana Shield has a long geological history, and its formation dates to the Precambrian ( 1.7 billion years ago). In contrast, the uplift of the Cordillera del Cóndor is much younger (5 - 10 million years ago) (Berry et al. 1995, Gregory-Wodzicki 2000, Schulenberg and Awbrey 1997). However, the phytogeography of these regions requires further study to better understand the distribution of plant species and the ecological and evolutionary processes associated with colonization and speciation processes in the area.

Pseudolycopodiella iuliformis is recorded from two sites in the Cordillera del Cóndor range close to the border of Ecuador and Peru. In Ecuador, the species is documented in two localities in the Zamora-Chinchipe Province: the Andean tepuis zone of Cerro Plateado Reserve (2400$2600 \mathrm{~m}$ ) and the Machinaza region (1500 m). In Peru, P. iuliformis occurs in the Condorcanqui Province of the Amazonas Department, at the summit of Cerro Machinaza (2160 m) (Figure 
2). Pseudolycopodiella iuliformis grows in humid habitats with sandstone soils, together with a dense layer of bryophytes, and it is surrounded by terrestrial bromeliads and sclerophyllous shrubs (Figure 3). According to specimen label notes (Pérez et al. 7365, 7468, 10080, 10083), associated species include Drosera condor Gonella, A. Fleischm. \& Rivadavia, Drosera peruensis T. Silva \& M.D. Correa, Everardia montana Ridl., Ladenbergia franciscana C.M. Taylor, Macrocarpaea subsessilis Weaver \& J.R. Grant, Miconia machinazana C. Ulloa \& D.A. Neill, Symbolanthus nebulosus J.E. Molina \& Struwe, and Ugni myricoides (Kunth) O. Berg, among others (Figure 3).

\section{Discussion}

Plants of P. iuliformis observed in the Ecuadorian and Peruvian Cordillera del Cóndor tend to form smaller mats with shorter strobiliferous branches than those found in the Guyana Shield; however, this range in morphological variation is consistent with the overall description of the species (Holub 1983, Øllgaard and Windisch 2016). Pseudolycopodiella iuliformis is distinguished from $P$. meridionalis and $P$. caroliniana var. mesetarum by its creeping shoots, which are entirely isophyllous (vs anisophyllous in P. meridionalis and P. caroliniana). In addition, P. iuliformis differs from $P$. contexta in two ways: 1 ) vegetative leaves with strobiliferous branches distant or subdistant, their bases flattened and appressed, often with slightly recurved tips; and 2) strobili appearing thicker than vegetative strobiliferous branches including the leaves (vs. vegetative leaves of erect, strobiliferous branches densely crowded, strongly ascending from an almost perpendicular, terete to angular leaf base; strobiliferous branches, including the leaves, appearing as thick as, or thicker than the strobilus in P. contexta).
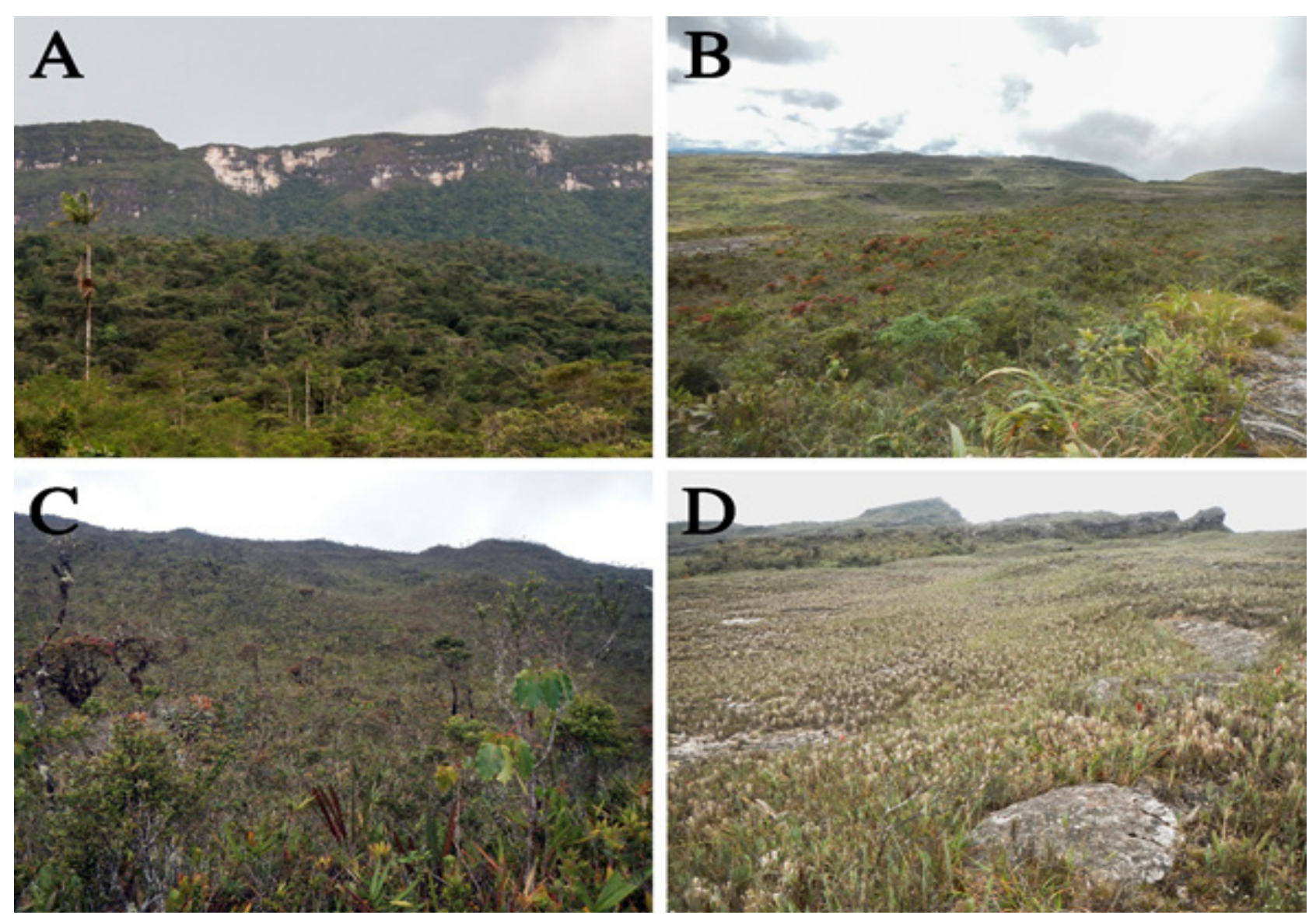

Figure 3. The habitat of Pseudolycopodiella iuliformis in the Andean tepuis: A. view of Cerro Machinaza from Río Blanco community in Zamora-Chinchipe, Ecuador. B. Vegetation at the summit of Cerro Machinaza (2400 m): scattered sclerophyllus shrubs, elfin forest, and open areas with sandstone outcrops. C. Elfin forest at the Cerro Plateado Reserve (2500 m). D. Vegetation at the summit of Cerro Plateado (2900 m). Photographs: A by Edison Rea; B, C, D by Álvaro J. Pérez. 
Currently, P. iuliformis presents a disjunct distribution (1500 km) between the Guyana Shield (southern Venezuela and adjacent Brazil) and the Cordillera del Cóndor range (Ecuador and Peru) (Figure 2). Both regions share similar abiotic conditions, with sandy, nutrient-poor, acidic soils. In the Cordillera del Cóndor range, P. iuliformis grows on a thick organic matter covered by bryophytes in open areas with sandstone outcrops or between terrestrial bromeliads and scattered sclerophyllous shrubs; all of which being habitats that dominate the Andean tepuis (Figure 3).

The complete distribution of P. iuliformis remains uncertain. More exploration is needed in the Cordillera del Cóndor range to understand the phytogeography of this highly diverse area and support conservation efforts in the face of deforestation and mining activities in the region (Mazabanda et al. 2018, Piotrowski and Ortiz 2019).

Specimens examined. ECUADOR. Zamora-Chinchipe: Cantón Nangaritza, Reserva Biológica Cerro Plateado, Colecciones en la meseta o tepuy andino sobre el campamento 2, 04³6'16"S 07849'16"W, 2400-2600 m, 22 Sep. 2016, Pérez et al. 10068 (QCA); 8 Aug. 2021, Pérez et al. 11708 (QCA). Cantón Yantzaza, Parroquia Los Encuentros, Campamento Las Peñas, entrada a la Cantera, área circundante al Cerro Machinaza, 0346'36"S, 78²9'53"W, 1500 m, 20 Oct. 2020, Zapata et al. 720 (QCA).

Additional specimens examined. PERU. Amazonas: Condorcanqui, Cima del Cerro Machinaza, Arriba del puesto de vigilancia Alfonso Ugarte (PV3), Meseta de roca arenosa con capa de humus, 352.7'S, 78²5.8'W, 2160 m, 31 Jul. 1994, Beltrán et al. 1529 (UC 2044145, USM 119241).

\section{Acknowledgements}

Fieldwork was granted by the Ministry of the Environment of Ecuador (MAE-DNB-ARRGGCM-2014-0002). We are grateful to the Secretaría de Educación Superior, Ciencia, Tecnología e Innovación de la República del Ecuador (SENESCYT, Arca de Noé Initiative, S. R. Ron and O. Torres-Carvajal, Principal Investigators) for financial support. Curators of cited herbaria allowed us to review the material. Finally, we thank the editors and two anonymous reviewers for their valuable suggestions that improved this paper.

\section{Declaration of interest and Authors' contributions}

All authors declare that there is no conflict of interest. AJP, NZ collected and photographed the plants in Ecuador. $B \varnothing, N Z$ and DC identified the specimens. AJP, CP, DC, DN, ER, KB, B, , and NZ wrote the text and revised herbarium collections. The Arca de Noe project and International Palm Society funded the fieldwork in Ecuador.

\section{References}

Berry PE; Huber O, Holst BK. 1995. Phytogeography of the Guayana Region. (Steyermark JA, Berry PE, Holst BK (eds) Flora of the Venezuelan Guayana: volume 1). Missouri Botanical Garden Press, St. Louis.

Gradstein SR, Reeb C, Persson C, Zapata N, Pérez ÁJ. 2019. Riccardia verticillata Gradst. \& Reeb, a new dendroid species of Riccardia (Aneuraceae) from the Cordillera del Cóndor, Ecuador. Journal of Bryology 41(4): 322-327.

Gregory-Wodzicki KM. 2000. Uplift history of the central and northern Andes: a review. Geological Society of America Bulletin 112: 1091-1105.

Holub J. 1983. Validation of Generic Names in Lycopodiaceae: with a Description of a New Genus Pseudolycopodiella. Folia Geobotanica et Phytotaxonomica 18: 439-442.

Mashburn B, Pérez ÁJ, Persson C, Zapata N, Cevallos D, Muchhala N. 2020. Burmeistera quimiensis (Lobelioideae, Campanulaceae): A new species from the Cordillera del Cóndor range in southeast 
Ecuador. Phytotaxa 433(1): 67-74.

Mazabanda C, Kemper R, Thieme A, Hettler B, Finer M. 2018. Impacts of mining project "Mirador" in the Ecuadorian Amazon. [Internet]. [accessed 2021 Jun 18]. https://maaproject.org/miradorecuador/

Neill DA. 2005. Cordillera del Cóndor: botanical treasures between the Andes and the Amazon. Plant Talk 41: 17-21.

Neill DA. 2007. Botanical exploration of the Cordillera del Cóndor region of Ecuador and Peru: project activities and scientific findings, 2004-2007. [Internet]. [accessed 2021 Jun 18]. http:// www.mobot.org/MOBOT/research/ecuador/cordillera/welcome.shtml

$\varnothing$ Ølgaard B. 2015. Six new species and some nomenclatural changes in Neotropical Lycopodiaceae. Nordic Journal of Botany 33: 186-196.

Øllgaard B. 2016. Additions, deletions and changes to the Ecuadorian Lycopodiaceae. Phytotaxa 246(2): 93-106.

Øllgaard B, Windisch PG. 2016. Lycopodiaceae in Brazil. Conspectus of the family II. The genera Lycopodiella, Palhinhaea, and Pseudolycopodiella. Rodriguésia 67(3): 691-719.

Pérez ÁJ, Persson C, Zapata N, Mashburn B, Vázquez-García JA. 2020. Magnolia lozanoi (Magnolia subsect. Dugandiodendron, Magnoliaceae) rediscovered on Ecuadorian "tepuis" in Reserva Biológica El Quimi, Cordillera del Cóndor: Critically endangered by open-pit mining. Phytotaxa 428: $255-262$.

Pérez ÁJ, Zapata N, Cevallos D, Persson C, Rea E, Øllgaard B. 2021. First record of Phlegmariurus pruinosus (Herter) B. Øllg. (Lycopodiaceae) for Ecuador from the Cordillera del Cóndor range. Revista Ecuatoriana de Medicina y Ciencias Biológicas 42(1): 57-62.

Piotrowski M, Ortiz E. 2019. Nearing the Tipping Point: Drivers of Deforestation in the Amazon Region. [Internet]. [accessed 2021 Mar 31]. https://www.thedialogue.org/analysis/nearing-thetipping-point-drivers-of-deforestation-in-the-amazon-region/

Schulenberg TS, Awbrey K. 1997. The Cordillera del Cóndor region of Ecuador and Peru: a biological assessment. RAP Working Papers 7. Conservation International, Washington, DC.

Ulloa Ulloa C, Acevedo-Rodríguez P, Beck S, Belgrano MJ, Bernal R, Berry PE, Brako L, Celis M, Davidse G, Forzza RC, Gradstein SR, Hokche O, León B, León-Yánez S, Magill RE, Neill DA, Nee M, Raven PH, Stimmel H, Strong MT, Villaseñor JL, Zarucchi JL, Zuloaga FO, Jørgensen PM. 2017. An Integrated Assessment of the Vascular Plants Species of the Americas. Science 358: 1614-1617.

Wurdack KJ. 2017. A new disjunct Dendrothrix (Euphorbiaceae, tribe Hippomaneae): a Guiana Shield element in sub-Andean cordilleras of Ecuador and Peru. PhytoKeys 86: 117-130. doi: 10.3897/phytokeys.86.14761 